\title{
Smart Cities using Internet of Things: Recent Trends and Techniques
}

\author{
Shagun Sharma, Mamta Nanda, Raghav Goel, Aashrey Jain, Megha Bhushan, Ashok Kumar
}

\begin{abstract}
A Smart Cities focuses on the way we live. Smart governments are also acknowledged as augmentations of electronic governments based on the Internet of Things (IoT). There are many existing challenges in the environment such as, research in gadgets, framework and programming etc. Particularly, the Smart Cities are facing difficulties with IoT frameworks, systems administration, independent registration, wearable sensors, gadgets and systematization of aggregates including human beings as well as programming specialists. This paper incorporates role of Smart Cities in various domains such as smart infrastructure, smart building, smart security and so on. Moreover, the work depicts the IoT technologies for Smart Cities and the primary components along with the features of Smart Cities. This paper is based on technologies for Smart Cities which will benefit citizens by facilitating a platform for integrating all the resources and prompt communication of information. Furthermore, merits, demerits and main challenges of Smart Cities are discussed.
\end{abstract}

Keyword: Smart Cities, IoT, Sensor System Integration, Smart technology, Smart citizens

\section{INTRODUCTION}

A city plays a significant role as revolutionary driver in various firms which is known as Smart Cities. In order to enhance the quality of life and innovation, Smart Cities involves ecosystems. The main aim of constructing a Smart Cities is to convert the rural area into urban area. Internet of Things (IoT) considered as a pillar of the Information and Communication Technologies (ICT) by using Smart Cities. IOT includes various semantic languages, digital identities and digital technologies which improve accuracy and efficiency of the innovation ecosystem. Its main aim is to improve the quality of life, for example, San Francisco park uses smart sensors to give instructions to the people about the available space in the parking lot and results in reducing or minimizing the waiting time. In this particular case, smart sensors collect the data and then transfer it to the devices through software or any other wireless connection. A new technology is developed using the combination of IOS (Internet of Services) and IOP (Internet of People).

IOS facilitates the use of various applications and semantics for better understanding, processing of data from different formats and providers. IOP facilitates the potential to interconnect, interact and interchange information among

Revised Manuscript Received on July 6, 2019.

Shagun Sharma, Mamta Nanda, Raghav Goel, Aashrey Jain and Megha Bhushan, Ashok Kumar, Chitkara University institute of engineering and Technology, Chitkara University, Punjab, India the people using intelligent network [1]. Smart Cities involves three pillars which include infrastructure, people planning and management.

The abundance and economic growth of Smart Cities are enhanced only with the support of open minded and inventive people. Living lab is an example of open innovation ecosystem which is used to combine research and innovation articles.

A city which utilizes various interrelated available information in order to comprehend its operations and uses limited resources is named as Smart Cities by IBM Company [2]. Since there are lot of changes from 90's to 20's in the technology, from launching a mobile phone to developing millions of the web applications. These web applications and mobile applications are controlling almost every area of the life and world around us. Various areas of the cities are totally dependent on these applications from money transfer to food delivery to traffic control to AC temperature control. Thus, the data involved in this is of heterogeneous type. To handle this type of data, sensors nodes are needed which should be highly efficient. A framework has been proposed that focuses on double abstraction of esoteric sensing and deals with heterogeneous type of data. The contiki operating system is used to implement the flexible and scalable infrastructure on the worldwide level. The purpose of this infrastructure is to enhance the scalability and flexibility of the heterogeneous data type.

Following is the skeleton of the paper: The basic terms are described in Section II. Section III includes the related work in Smart Cities using IoT. Section IV summarizes the technologies for Smart Cities. Section V incorporates the research gaps identified in the area of Smart Cities. Finally, the conclusion is given in section VI.

\section{BACKGROUND}

This section includes the basic terms used in Smart Cities.

\section{A. Smart Cities}

A Smart Cities assimilates the ICT to enhance the performance and quality of services in metropolitan cities which include transportation or energy sources [3]. A wide idea of Smart Cities is to improve the quality of welfare and living of its citizens through smart technologies.

Following are the components of Smart Cities as shown in Fig. 1 [4-6]:

\section{1) Smart citizen}

Smart Cities consist of smart citizens or people who are living their life smartly by using

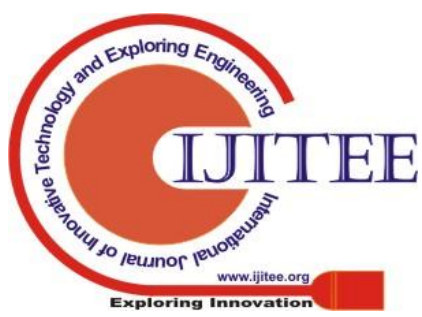


smart devices i.e. smart phones, smart cars, smart building etc.

\section{2) Smart environment}

Smart environment involves smart devices i.e. smart sensors, automatic remotes etc. to use and control the environment smartly.

\section{3) Smart home}

A smart home can be operated and controlled remotely by smart devices or sensors.

\section{4) Smart cars}

Smart cars are the processed form of emerging IoT systems with the existing cars, and the formed devices are called smart cars.

\section{5) Smart technology}

It contains devices which increase the quality of cities and enable smart citizens to make use of this technology.

\section{6) Smart transport}

Smart transport improves the mobility and decreases the traffic congestion by using smart devices.

\section{7) Smart retail}

It allows retailers to use smart devices or smart ideas for retailing their product smartly.

\section{8) Smart security}

Smart security facilitates smart citizens to protect their smart home, smart cars and other smart devices from cyber theft etc.

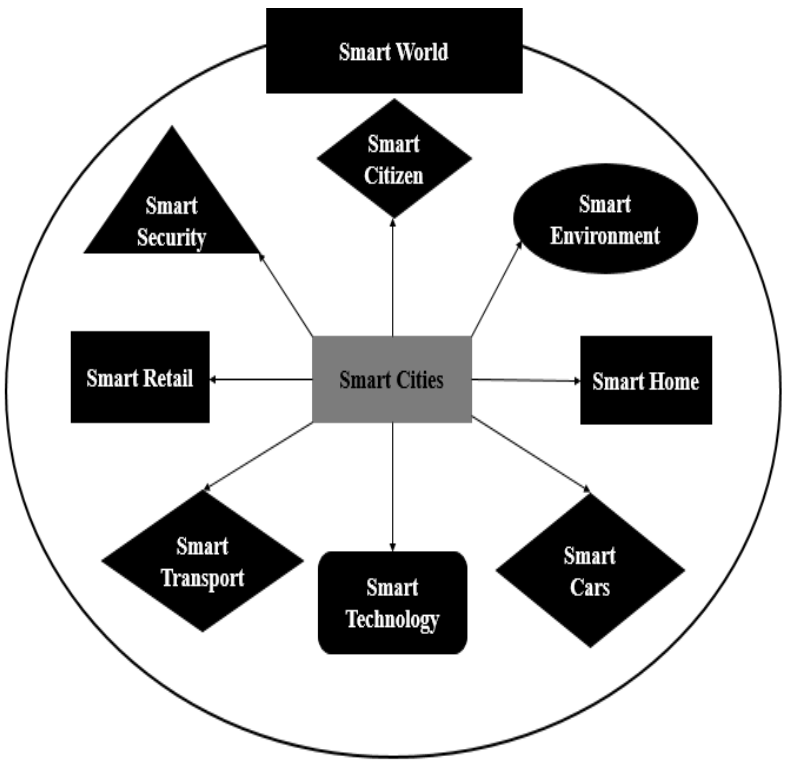

Fig. 1. Components of Smart Cities

\section{B. Internet of things (IoT)}

It is a network that contains physical objects which include the latest embedded technologies [3]. These technologies can efficiently communicate, sense, and transact with the interior and exterior impacts of their environment. IoT is an arrangement of interconnected computing devices, digital technologies, objects and citizens. It transfers the information and data over network without the need of computer to human, human to computer and human to human interactions. There are many technologies used in IoT as shown in Fig. 2 $[5,7]$.

\section{Wireless Sensor Networks (WSN)}

It is a network, formed of various small sensor nodes, and can act as a gateway or path for data transmission [6]. This network is highly efficient and capable of communicating with data gathered from heterogeneous sources via wireless links or connections.

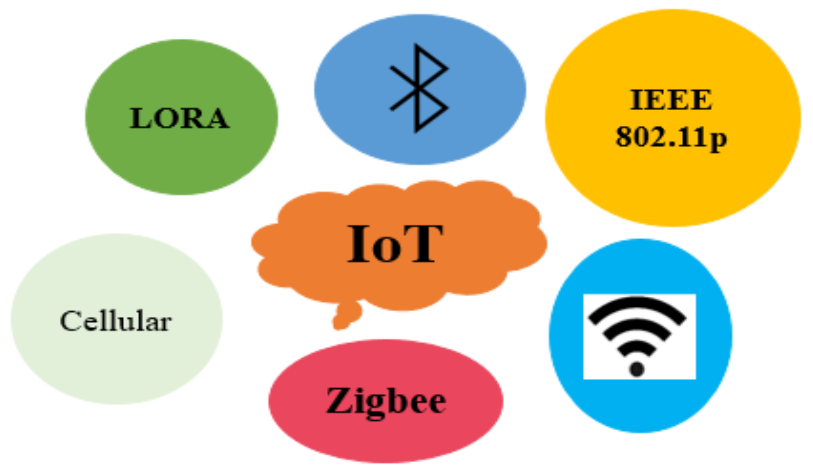

Fig. 2. Technologies used in IoT

\section{Intelligent Cities}

Intelligent cities are the one where internet, mobile and development and reduction of human efforts to perform various tasks [8]. An intelligent city aims to enhance the efficiency of resources being consumed and reduce the cost of various services.

\section{LITRATURE REVIEW}

In this section, literature related to the latest technologies for Smart Cities using IOT are discussed.

In context with Open Innovation and IoT, Smart Cities development has been explored in [1]. Smart Cities leads to an economic growth as these cities are comprised of entrepreneurial capital, social capital and human capital. Smart Cities projects by IBM were used for performing empirical testing to investigate the relationship between Smart Cities and IoT by using an Open Innovation (OI) model.

At the level of project portfolio, better ambidexterity performance was attained by developing capabilities i.e. knowledge management (KM) integrated with ICT for multinational enterprises (MNEs) [3]. The data used for it was gathered from 43 IoT Smart Cities project alliances in Italy. Developing ICT skills and designing KM tools by MNE managers were suggested as ICT capabilities can indirectly enhance ambidexterity. Further, implications for managers and academics were provided.

Smart governments are categorized into two kinds, recent generation and broaden smart government. A framework was used for smart government enactment and later, discussed the utmost issues in its implementation and resulted security as the major issue [7]. This framework provided main challenges in the Smart Cities, and identified mind scaping, investment, and security \& privacy, and as the biggest challenges for Kuwait, India and United States, respectively.

In Smart Cities of India (SCI), various factors have been identified that affected the success of information system by integrating IoT with Artificial Intelligence (AI) [4]. Further, IoT used by the smart residents of SCI is affected by Perceived System Quality (PSQ) and Perceived Information Quality (PIQ). In order to realize desired success, the usage of IoT in SCI by users should be enhanced by improving the success of information system, it can be attained by the focus of SCI authorities on better information and system quality. Further, more

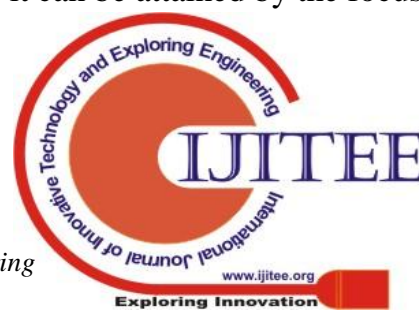


citizens can be induced to use IoT by deriving Perceived Net Benefit (PNB) from the fulfilment of usage of IoT.

The wireless technologies for Smart Cities have been reviewed, compared and their trends are also presented [5]. The results conclude that it is beneficial for both research and commercial domains. The systems and services become inoperable due to the mismanagement of security and bandwidth usage of wireless networks. Further, futuristic developments and demands are also provided for the researchers.

In IoT-based Smart Cities, various issues were discussed for autonomous and wearable devices [9.6]. It needs research on software, infrastructure and devices. The issues related to wireless communication, energy management, and IoT devices and systems.

The combination of KM (Knowledge Management) and ICT capabilities was tested in order to obtain maximum ambidexterity performance [3]. Accentuated alliance ambidexterity can increase the KM capabilities by using three main theoretical benefactions, i.e., addition of knowledge on the management of ambidexterity, IoT and Smart Cities which give some particular and different range of employees involved.

A review on variant features, characteristics, motivations, applications and concepts of Smart Cities is given [6]. Further, IoT technologies for these cities are described and used to develop as well as enhance daily activities, followed by explaining the identified issues during implementation of IoT system.

In IoT, an automating design methodology (ADM) was developed using ontology for smart rehabilitation systems [10]. Based on the specific requirements of patient, a rehabilitation strategy is created and medical resources are reconfigured using the comprehended symptoms and medical resources by the ontology. An immediate information interaction is provided by interconnecting each resource on the platform given by the IoT. Later, the missing representations of Smart Cities are suggested in [8].

In order to comprehend the place of IoT in the Future Internet, features and security problems of the distributed approach of the IoT are analyzed [11]. Multiple properties and benefits are also shown.

Due to an instant growth in the count of smart devices coupled with different type of devices, communications and applications, scalability becomes the main issue during huge deployment of sensor(s) and its environment [12]. The connectivity between people to people and information to people using internet, allows the areas, objects and many of the things to get connected with one another. Due to this context, the internet has been developed as a smart platform which enables smart services.

\section{SUMMARY OF STATE OF THE ART}

This section summarizes existing literature work on Smart Cities using IoT as shown in Table 1

Table 1: Summary of various technologies for Smart Cities

\begin{tabular}{|c|c|c|c|c|c|}
\hline Articles & Year & Summary & Tools and Techniques & Merits & Demerits \\
\hline$[1]$ & 2016 & $\begin{array}{l}\text { - joint effort of Capital, } \\
\text { social capital, } \\
\text { entrepreneurship capital } \\
\text { increase the economic } \\
\text { growth in Smart Cities }\end{array}$ & $\begin{array}{l}\text { ICT tools } \\
\text { - Experimental } \\
\text { technology platforms } \\
\text { - e-service } \\
\text { applications } \\
\end{array}$ & $\begin{array}{l}\text { - Enhance and improve the } \\
\text { quality by using } \\
\text { innovation ecosystem }\end{array}$ & $\begin{array}{l}\text { - Empirical analysis } \\
\text { has been developed } \\
\text { to improve the } \\
\text { multinational firm }\end{array}$ \\
\hline$[2]$ & 2012 & $\begin{array}{l}\text { - Smart Cities with mobile } \\
\text { technologies required } \\
\text { highly efficient sensor } \\
\text { nodes to deal with } \\
\text { heterogeneous data } \\
\end{array}$ & 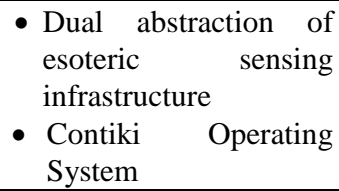 & $\begin{array}{l}\text { - Operating system } \\
\text { provided a scalable and } \\
\text { flexible infrastructure }\end{array}$ & $\begin{array}{ll}\text { - No } & \text { support for } \\
\text { data } & \text { aggregation } \\
\text { and data filtering }\end{array}$ \\
\hline [3] & 2018 & $\begin{array}{l}\text { - Maximum ambidexterity } \\
\text { performance can be } \\
\text { obtained by combination } \\
\text { of KM and ICT } \\
\text { capabilities }\end{array}$ & - KM tool & $\begin{array}{l}\text {-Intensive use of new } \\
\text { technologies }\end{array}$ & $\begin{array}{c}\text { - Low ICT } \\
\text { capabilities }\end{array}$ \\
\hline [4] & 2018 & $\begin{array}{l}\text { - IoT analyzed the } \\
\text { conciliation of three } \\
\text { components } \\
\text { internet- person to person } \\
\text { interaction, person to } \\
\text { things interaction and an } \\
\text { interaction between things } \\
\text { to things }\end{array}$ & $\begin{array}{l}\text { - Information } \\
\text { success model }\end{array}$ & 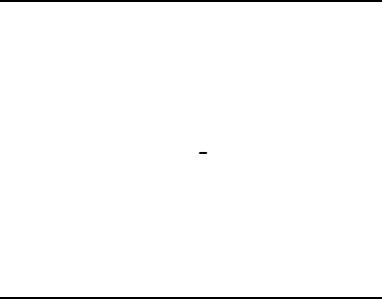 & $\begin{array}{l}\text { - PIQ has } \\
\text { influence }\end{array}$ \\
\hline [5] & 2017 & $\begin{array}{l}\text { - Provided an infrastructure } \\
\text { has been provided by the } \\
\text { revolution of the Internet } \\
\text { in which many people } \\
\text { interconnected to each } \\
\text { other. } \\
\text { - Provides suitable } \\
\text { interconnections among } \\
\text { objects }\end{array}$ & $\begin{array}{l}\text { - Radio-Frequency } \\
\text { Identification (RFID), } \\
\text { WSN }\end{array}$ & $\begin{array}{l}\text { - Provided a suitable } \\
\text { platform to analyze and } \\
\text { integrate data from different } \\
\text { devices. }\end{array}$ & $\begin{array}{l}\text { - Overcome required } \\
\text { for the privacy rights } \\
\text { of the citizens }\end{array}$ \\
\hline
\end{tabular}




\begin{tabular}{|c|c|c|c|c|c|}
\hline$[6]$ & 2016 & $\begin{array}{l}\text { - Sensing and networking } \\
\text { process are some processes } \\
\text { of IoT technology which } \\
\text { increase the chance for } \\
\text { scheduling of energy } \\
\text { supplier ideally. }\end{array}$ & $\begin{array}{l}\text {-IoT technology } \\
\text { - RFID }\end{array}$ & $\begin{array}{l}\text { - Self-organizing property of } \\
\text { objects }\end{array}$ & - \\
\hline [7] & 2014 & $\begin{array}{l}\text { - Transceivers for digital } \\
\text { communication, and } \\
\text { suitable protocol stacks } \\
\text { allowed to interact with } \\
\text { the users and became an } \\
\text { integral part of the Internet }\end{array}$ & - ReST paradigm,XML & $\begin{array}{l}\text { - Capability of integrating } \\
\text { different technologies with } \\
\text { the existing } \\
\text { communication } \\
\text { infrastructures }\end{array}$ & - \\
\hline [8] & 2011 & $\begin{array}{l}\text { - Analyzed difference } \\
\text { between intelligent cities } \\
\text { and Smart Cities }\end{array}$ & $\begin{array}{l}\text { - Analysis based on } \\
\text { various innovation } \\
\text { techniques used in } \\
\text { Smart Cities } \\
\text { enhancements }\end{array}$ & $\begin{array}{l}\text { - Smart Cities work for the } \\
\text { development, keeping } \\
\text { human welfare in mind } \\
\text { whereas Intelligent cities } \\
\text { mostly focuses on money } \\
\text { making while } \\
\text { development is done }\end{array}$ & - \\
\hline [9] & 2018 & $\begin{array}{l}\text { - Focused on the difficulties } \\
\text { in the implementation of } \\
\text { smart governments }\end{array}$ & $\begin{array}{l}\text { - Investment } \\
\text { - Security and Privacy }\end{array}$ & $\begin{array}{l}\text { - Offers a single layer } \\
\text { interaction channel }\end{array}$ & $\begin{array}{l}\text { More risk of } \\
\text { security attacks }\end{array}$ \\
\hline [10] & 2017 & $\begin{array}{l}\text { - Energy Harvesting (EH) } \\
\text { recommended the } \\
\text { prospective for contexture } \\
\text { systems to work in the } \\
\text { absence of batteries } \\
\text { (independent devices), by } \\
\text { producing electrical power } \\
\text { from number of sources } \\
\text { indulging light, vibration, } \\
\text { motion or temperature } \\
\text { distinctions }\end{array}$ & $\begin{array}{l}\text { - Energy-driven } \\
\text { applications, } \\
\text { Networking with } \\
\text { transiently-powered } \\
\text { devices }\end{array}$ & $\begin{array}{l}\text { - Interconnection, } \\
\text { Reliability }\end{array}$ & $\begin{array}{l}\text { - Electronics should } \\
\text { be flexible, } \\
\text { stretchable and } \\
\text { washable. } \\
\text { - Wearable } \\
\text { electronics should } \\
\text { be robust, small } \\
\text { and contains low } \\
\text { power operation }\end{array}$ \\
\hline [11] & 2014 & $\begin{array}{lrr}\text { •For shrewd } & \text { recovery } \\
\text { frameworks in } & \text { IOT a } \\
\text { metaphysics } & \text { based } \\
\text { mechanizing } & \text { structure } \\
\text { methodology } & \text { has been } \\
\text { Introduced. } & & \end{array}$ & $\begin{array}{l}\text { - IOT - based } \\
\text { rehabilitation system, } \\
\text { automating } \\
\text { methodology in the } \\
\text { framework of IOT. }\end{array}$ & $\begin{array}{l}\text { - An ontology-based } \\
\text { automatic design } \\
\text { methodology for smart } \\
\text { rehabilitation system using } \\
\text { IOT technology is } \\
\text { presented. }\end{array}$ & - \\
\hline [12] & 2013 & $\begin{array}{l}\text { - Analysis of different } \\
\text { security challenges. } \\
\text { - Analysis of centralized } \\
\text { and distributed } \\
\text { approaches. } \\
\text { - Implemented various } \\
\text { approaches in order to } \\
\text { solve security issues } \\
\text { - In the deployment of } \\
\text { security mechanism } \\
\text { various promising } \\
\text { solutions has been } \\
\text { introduced }\end{array}$ & - & $\begin{array}{l}\text { - Elaborated and overcame } \\
\text { some security challenges } \\
\text { of various internet of } \\
\text { things }\end{array}$ & $\begin{array}{l}\text { - Not solved and } \\
\text { managed the } \\
\text { authentication and } \\
\text { authorization of the } \\
\text { entities. }\end{array}$ \\
\hline [13] & 2012 & $\begin{array}{l}\text { - Discussed about how to } \\
\text { use Mobile phones and } \\
\text { technologies to make } \\
\text { normal cities to Smart } \\
\text { Cities }\end{array}$ & $\begin{array}{l}\text { - Cloud and Internet via } \\
\text { mobile applications }\end{array}$ & $\begin{array}{l}\text { - Improves the efficiency of } \\
\text { mobile applications. }\end{array}$ & $\begin{array}{l}\text { - Privacy, } \\
\text { scalability, Security, } \\
\text { authentication are a } \\
\text { major concern }\end{array}$ \\
\hline [14] & 2011 & $\begin{array}{l}\text { - Students are considered as } \\
\text { the major role for } \\
\text { improving the relationship } \\
\text { between urban populace } \\
\text { progress and human } \\
\text { capital }\end{array}$ & $\begin{array}{ll}\text { - Large } & \text { literature } \\
\text { approach } & \end{array}$ & $\begin{array}{l}\text { - Smart Cities } \\
\begin{array}{l}\text { form } \\
\text { centers of } \\
\text { education }\end{array}\end{array}$ & $\begin{array}{l}\text { - Increase in } \\
\text { population due to } \\
\text { increase in Smart } \\
\text { Cities }\end{array}$ \\
\hline
\end{tabular}

\section{GAPS IDENTIFIED}

In Smart Cities, there is a need to explore whether the abilities of KM and ICT play the equivalent job in other innovative technologies. Innovative parts of IoT can be considered by researchers in SCI. Thus, a study is required on various metropolitan urban areas of country [3]. Further, a structured survey is required for targeting government and

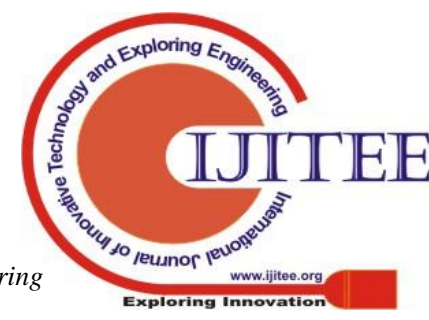


private organizations to understand mindset of citizens [9]. There is a need to focus on data aggregation and data filtering so that more efficient system could be used for enhancing the Smart Cities implementation [2].

\section{CONCLUSIONS}

The idea of IoT is the inescapable nearness of things and items that are interconnected to coordinate with one another to achieve a shared objective. The integration of IoT with different intelligent systems, is the main feature for the implementation of smart applications in Smart Cities. This paper will benefit the researchers and academia by providing detailed information on the use of IoT for the development of Smart Cities, which includes summary of existing approaches, tools and techniques, merits along with demerits.

\section{REFERENCES}

1. Scuotto, Veronica, Alberto Ferraris, and Stefano Bresciani. "Internet of Things: Applications and challenges in Smart Cities: a case study of IBM Smart Cities projects." Business Process Management Journal 22.2 (2016): 357-367.

2. Fazio, M., Paone, M., Puliafito, A., \& Villari, M. (2012, July). Heterogeneous sensors become homogeneous things in Smart Cities. In 2012 Sixth International Conference on Innovative Mobile and Internet Services in Ubiquitous Computing (pp. 775-780). IEEE.

3. Bresciani, S., Ferraris, A., \& Del Giudice, M. (2018). The management of organizational ambidexterity through alliances in a new context of analysis: Internet of Things (IoT) Smart Cities projects. Technological Forecasting and Social Change, 136, 331-338.

4. Chatterjee, S., Kar, A. K., \& Gupta, M. P. (2018). Success of IoT in Smart Cities of India: an empirical analysis. Government Information Quarterly, 35(3), 349-361.

5. Zhu, H., Chang, A. S., Kalawsky, R. S., Tsang, K. F., Hancke, G. P., Bello, L. L., \& Ling, W. K. (2017, October). Review of state-of-the-art wireless technologies and applications in Smart Cities. In IECON 2017-43rd Annual Conference of the IEEE Industrial Electronics Society (pp. 6187-6192). IEEE.

6. Arasteh, H., Hosseinnezhad, V., Loia, V., Tommasetti, A., Troisi, O., Shafie-Khah, M., \& Siano, P. (2016, June). Iot-based Smart Cities: a survey. In 2016 IEEE 16th International Conference on Environment and Electrical Engineering (EEEIC) (pp. 1-6). IEEE.

7. Zanella, A., Bui, N., Castellani, A., Vangelista, L., \& Zorzi, M. (2014). Internet of things for Smart Cities. IEEE Internet of Things journal, 1(1), 22-32.

8. Deakin, Mark, and Husam Al Waer. "From intelligent to Smart Cities." Intelligent Buildings International 3.3 (2011): 140-152.

9. AlEnezi, A., AlMeraj, Z., \& Manuel, P. (2018, April). Challenges of IoT based smart-government development. In 2018 21st Saudi Computer Society National Computer Conference (NCC) (pp. 1-6). IEEE.

10. Balsamo, D., Merrett, G. V., Zaghari, B., Wei, Y., Ramchurn, S., Stein, \& Beeby, S. (2017, September). Wearable and autonomous computing for future Smart Cities: Open challenges. In 2017 25th International Conference on Software, Telecommunications and Computer Networks (SoftCOM) (pp. 1-5). IEEE.

11. Fan, Y. J., Yin, Y. H., Da Xu, L., Zeng, Y., \& Wu, F. (2014). IoT-based smart rehabilitation system. IEEE transactions on industrial informatics, 10(2), 1568-1577.

12. Roman, Rodrigo, Jianying Zhou, and Javier Lopez. "On the features and challenges of security and privacy in distributed internet of things." Computer Networks 57.10 (2013): 2266-2279.

13. Balakrishna, Chitra. "Enabling technologies for Smart Cities services and applications." 2012 sixth international conference on next generation mobile applications, services and technologies. IEEE, 2012.

14. Winters, John V. "Why are Smart Cities growing? Who moves and who stays." Journal of regional science 51.2 (2011): 253-270

\section{AUTHORS PROFILE}

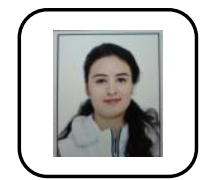

Shagun Sharma is presently pursuing Masters of Engineering from Chitkara University and also working as an Assistant Lecturer. She has done her Bachelor of technology from Shoolini University of biotechnology

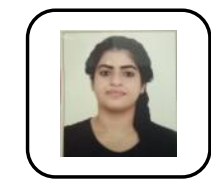

and management sciences. She is one of the ten toppers in the graduation. Her area of interest includes, Data Mining and Machine Learning.

Mamta Nanda is currently pursuing Masters of Engineering from Chitkara University and also working as an Assistant Lecturer. She has done her Bachelor of technology from Malout Institute of Management and Information Technology, Malout.

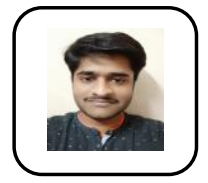

Raghav Goel is presently pursuing Bachelor of Engineering in CSE from Chitkara University and also working on a review entitled with smart stick for blinds.

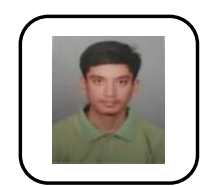

Aashrey Jain is currently pursuing Bachelor of Engineering in CSE from Chitkara University and is also working on a review on smart stick for blinds.

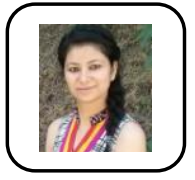

Dr. Megha is currently an Assistant Professor in Chitkara University Research and Innovation Network (CURIN) Department, Punjab. She is PhD in Computer Science and Engineering from Thapar University, Punjab, India and has received fellowships during her PhD. She has 4 years of research experience as JRF and SRF under University Grants Commission (UGC), New Delhi, Government of India Her research interest includes Software quality, Software reuse, Software product line, Ontologies and Expert systems. Her teaching interest includes Software engineering, Software testing and Software project management. She has research publications in International journals and Conferences of repute. She is also the editorial board member of many International journals.

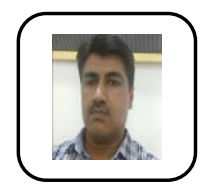

Dr. Ashok Kumar is currently an Assistant Professor in Chitkara University Research and Innovation Network (CURIN) Department, Punjab. He is PhD in Computer Science and Engineering from Thapar University, Punjab, India. He has 15+ years of teaching and research experience. He has number of publications in International Journals and Conferences of repute. His current areas of research interest includeCloud Computing, Internet of Things, and Mist Computing. His teaching interest includes Python, Haskell, Java, C/C++, Advanced Data structures, and Data Mining. 